\title{
Higher Order Thinking Skills (Hots) Instrument Based on Tri Hita Karana on Theme "The Beauty of Diversity in My Country"
}

\section{Wayan Sariarta ${ }^{*}$, Ni Wayan Rati2}

1,2 Jurusan Pendidikan Dasar, Universitas Pendidikan Ganesha, Singaraja Indonesia

\section{ART ICLE INF O}

Article history:

Received August 07, 2021

Revised August 11, 2021

Accepted September 30, 2021

Available online October 25, 2021

Kata Kunci:

HOTS, Tri Hita Karana, Instrumen

Keywords:

HOTS, Tri Hita Karana,

Instrument

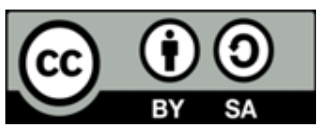

This is an open access article under the CC BY-SA license.

Copyright $\Subset 2021$ by Author. Published by Universitas Pendidikan Ganesha.

\begin{abstract}
ABST RAK
Rendahnya pemahaman guru terhadap instrumen HOTS sehingga rendahnya kemampuan siswa dalam memecahkan masalah. Tujuan penelitian ini adalah menghasilkan instrumen HOTS berbasis Tri Hita Karana pada Tema 7 (Indahnya Keberagaman di Negeriku) kelas IV SD yang valid secara isi, valid secara butir, reliabel, baik dilihat dari aspek daya beda, dan baik dilihat dari aspek tingkat kesukaran. Jenis penelitian ini adalah penelitian pengembangan berpedoman pada prosedur model Borg dan Gall. Model Borg and Gall dengan enam tahapan yaitu penelitian dan pengumpulan data, perencanaan, pengembangan produk awal, uji coba lapangan awal (terbatas), revisi hasil uji lapangan terbatas, dan diseminasi dan implementasi. Instrumen HOTS berbasis Tri Hita Karana berupa tes dengan bentuk pilihan ganda. Subjek dalam penelitian ini adalah 5 pakar ahli instrumen. Sedangkan objek dalam penelitian ini yaitu kualitas butir soal. Data yang dikumpulkan dalam penelitian ini yaitu data mengenai instrumen kemampuan HOTS. Metode yang digunakan untuk mengumpulkan data dalam penelitian ini adalah metode tes. Data dianalisis dengan menggunakan uji analisis validitas isi, uji validitas butir, uji reliabilitas, uji tingkat kesukaran dan uji daya beda. Hasil uji validitas isi yang diuji oleh lima pakar instrumen HOTS dinyatakan relevan, ratarata hasil uji validitas butir instrumen di tiga sekolah dinyatakan valid, ratarata hasil uji reliabilitas instrumen sebesar 0,931 yang berada pada kriteria sangat tinggi, hasil rata-rata skor tingkat kesukaran butir soal sebesar 0,545 yang berada pada kategori sedang, hasil rata-rata uji daya beda sebesar 0,5 yang berada pada kriteria daya beda baik. Sehingga instrumen HOTS berbasis Tri Hita Karana pada tema 7 (Indahnya Keberagamaan di Negeriku) layak digunakan untuk mengukur kemampuan HOTS siswa dalam memecahkan masalah.
\end{abstract}

\section{A B S T R A C T}

\begin{abstract}
This study aimed for the HOTS instrument based on Tri Hita Karana in Theme 7 (The Beauty of Diversity in my Country) grade IV SD, which is valid in content, valid in points, reliable, and good in distinguishing power and good in terms of difficulty level. The development of the instrument in this study was guided by the Borg and Gall model procedure with six stages, namely research and data collection, planning, initial product development, initial (limited) field trial, revision of limited field test results, and dissemination and implementation. The HOTS instrument based on Tri Hita Karana is in the form of a multiple-choice test. While the object in this study is the quality of the items. The data collected in this study is data regarding the HOTS ability instrument. The method used to collect data in this study is the test method. The data were analyzed using content validity analysis test, item validity test, reliability test, difficulty level test and different power test. The results of the content validity test tested by five experts on the HOTS instrument were stated to be relevant. The average instrument item validity test results in three schools were declared valid. The average instrument reliability test results were 0.931 which were in very high criteria, the average score level results. The difficulty of the items is 0.545 which is in the medium category, the average result of the difference power test is 0.5 which is in the good power criterion. So the HOTS instrument based on Tri Hita Karana on theme 7 (The Beauty of Religion in My Country) is suitable for measuring HOTS students' ability to solve problems.
\end{abstract}




\section{INTRODUCTION}

The education process cannot be separated from the assessment process. With the assessment process, it will be known the ability of students both knowledge, attitudes, and skills of students after carrying out the learning process (Schildkamp et al., 2020; Zhang, 2020). The existence of an assessment process provides an opportunity to find out how the current learning conditions are (Msosa et al., 2021). 21st-century education assessment should be designed to measure the achievement of competency or material authentically. Indonesian education in the 21st century is faced with choices due to changes in the strategic environment that are complex, unpredictable, unstable, uncertain, and limited educational resources (Slamet, 2016). The demands of 21st-century assessment focus on measuring students' ability to think critically, solve problems, gather information, and make sound decisions (Winaryati, E., 2018). In addition, the demands in the 21st-century assessment are to prepare children to be ready to face challenges in the complex global environment in the future (Bahasoan et al., 2020). Teachers must be facilitators and design problem-based learning for students (Kwangmuang, 2021). Thus, 21st-century assessment must be authentic, focusing on students' critical thinking skills or HOTS abilities.

HOTS is a higher order thinking process developed from various cognitive concepts and methods and taxonomies of learning such as problem-solving methods, Bloom's taxonomy, and learning taxonomy (Saputra, 2016). HOTS is an ability that doesn't just rely on memory but is a complex thinking effort that involves critical and creative thinking skills in solving problems faced to obtain solutions (Anggraini et al., 2019; Dinni, 2018; P. H. Pratiwi, 2017; Rahayu et al., 2021). HOTS is a complex thinking ability that involves all previous aspects to produce a solution (Arifin \& Retnawati, 2017). HOTS is a thinking ability that is tested at a higher level, meaning that it is not only tested on aspects of student memory, but HOTS tests on aspects of analyzing (C4), evaluating (C5), and creating (C6) (Hosnan, 2014). HOTS requires students to apply new information and manipulate it to reach possible answers in new situations (Hanik \& Ngazizah, 2020). Higher order thinking skills can make an individual interpret, analyze or manipulate the information obtained (Noprinda \& Soleh, 2019; P. H. Pratiwi, 2017). Developing the HOTS ability requires the teacher to provide a stimulus that follows the HOTS ability through the provision of problems (Nisa \& Pahlevi, 2021; Wulandari et al., 2020). HOTS problems are characterized by an assessment based on real problems in students' daily lives (Khotimah \& Sari, 2020). One of the ways used to provide stimulus problems is by giving questions (Wahyudin et al., 2017) whose indicators are at the Cognitive level C4, C5 and C6. (Sufairoh, 2016). These three aspects will certainly be able to develop students' higher order thinking skills (Susilana, \& Rusman., 2015).

However, the facts show that the current assessment system design is too focused on measuring students' ability to remember facts and there are very few HOTS questions in it. The HOTS instrument is still very rare to be developed at the elementary school level (Lestari, 2016). The assessment tool provided only measures the level of remembering and understanding. The quality of students' thinking is still at a low level with limited ability to remember something (Nursamsu dan Baihaqi, 2016). The questions made by the teacher during learning in the written test are still dominated by low-level thinking skills such as using "what" and "say" (Dahlan, 2010). The low ability of Indonesian students to apply higher order thinking skills shows that the quality of education in Indonesia still needs to be improved in many ways, including increasing teacher competence, one of which is to build questions to measure students' higher order thinking skills (Pratiwi, 2017). Of course, this is a problem because 21st-century assessment demands to measure students' higher-order thinking in which the assessment tool used must be able to measure HOTS abilities. Regarding the HOTS, assessments or questions require higher-order thinking skills (Safi'i, I dan Amar, F., 2019). In shaping the quality of students to be better, these kinds of questions must be developed by the teacher properly and applied in the class they are teaching (Sudarsana, 2018). The assessment carried out in the past was only with a summative test, where the summative test usually did not contain HOTS questions (Fitriani et al., 2018). Based on this, the questions given by the teacher to students are still very minimal in HOTS elements in it. The cause of the problem is the teacher's lack of understanding about the HOTS question instrument. Likewise, the results of the teacher's observations and analysis of the UTS items showed that the HOTS questions were still very minimal, $16 \%$ of the total questions. Thus, students' higher-order thinking skills are not measured optimally.

Based on the problems above, the solution that can be given is to develop an assessment tool following the demands of 21st-century education, namely the HOTS instrument. The preparation of questions is seen as more effective if associated with phenomena in everyday life. Several studies that have been carried out include research that states that the HOTS questions on algebraic material meet the Valid, Practical and Effective criteria. Valid because all validators reported that the developed HOTS questions were available and the average scores for content, composition and language validation were within the very valid criteria. Practical because all validators have stated that the developed questions can be used in class. It is effective because students' answers to these questions are positive and students' abilities in

I Wayan Sariarta / Higher Order Thinking Skills (Hots) Instrument Based on Tri Hita Karana on Theme "The Beauty of Diversity in My Country" 
solving these problems vary (Wulandari et al., 2020). Research shows that the test instrument was developed with a 4D model, the feasibility of the test instrument getting an overall average of 3.8 with very good criteria and getting a PA of 93.5\% with reliable criteria, the response with 6 students getting a percentage of $76.4 \%$ with positive criteria. The response with 11 students got a percentage of $93.9 \%$ with very positive criteria, the implementation of the first learning got $87.7 \%$ PA, the second meeting got $89.7 \%$ PA and the third meeting got 91.7\% PA so that we get reliable criteria (Hanik \& Ngazizah, 2020). This research is also supported by research showing that the HOTS-based assessment instrument developed in the form of 15 multiple choice questions and 5 description questions on the material, construction, and language aspects was declared theoretically valid based on expert judgment and empirically valid and reliable instrument based on the results of field trial analysis (Rusudianto et al., 2020). Research states that HOTS is the highest level in the hierarchy of cognitive processes. HOTS enables students to tackle the challenges of being too informational in this information age, but time for processing is limited. HOTS occurs when a person acquires new information, stores it in memory, organize it, relates it to existing knowledge, and generates this information to achieve a goal or solve a complex problem (Yee et al., 2015). So, the HOTS instrument it will make learning more interesting.

The difference between this research and the existing one is that the development of the HOTS instrument is associated with the Tri Hita Karana concept. Tri Hita Karana is the three causes of the creation of happiness: the relationship between humans and God, the relationship between humans and humans, and the relationship between humans and the environment (Suarmini, 2019). Tri Hita Karana is three things that cause humans to achieve prosperity, happiness, and peace (Arsana \& Muniksu, 2020; Putra et al., 2014). The application of Tri Hita Karana is a very important thing in maintaining harmony and balance in this world. Windia (2010). Tri Hita Karana means three causes of harmony (Palguna, 2011). Tri Hita Karana is three teachings to achieve human welfare for society (Jaya, 2019). Tri Hita Karana is philosophical teaching of Hinduism that exists in aspects of the lives of indigenous peoples in the Bali region. Tri Hita Karana is a basis for getting the happiness of human life.

With this concept, a relationship between humans and God is built because humans are not created alone. In various communities of creatures, humans must also build harmonious relationships with the various communities of these creatures (Mudana, 2017). The concept of Tri Hita Karana which has been described above both from scripture verse and expert opinion can be stated that the pattern of relationships created in the concept of Tri Hita Karana in building character and spirituality of students at school is to always be based on the basic principle of the existence of a divine element. (Padnyawathi \& Agustika, 2019). It means that the relationship of Tri Hita Karana in building the character and spirituality of students at school must always be based on a belief that: (1) all human activities are based on teachings that come from God; (2) all human activities are known and witnessed by God; (3) all human activities are aimed as offerings to God (Yunita \& Tristiantari, 2018). By paying attention to the pattern of relationships that are formatted in the concept of Tri Hita Karana, it conceptually guarantees the realization of students who are religious, religious, honest, loyal, noble, responsible, moral, ethical, polite, compassionate, affectionate and love all of God's creation. Suppose all students can foster this harmony with high discipline by their respective obligations. In that case, the student's character will be strong in facing the competition of life in this modern era (Suarmini, 2019). With this understanding, the concept of Tri Hita Karana is very closely related to our daily lives. The questions presented lead to problems in everyday life in which there is the concept of Tri Hita Karana. The Tri Hita Karana concept in this instrument can facilitate the preparation of questions and make it easier for students to solve the problems in the questions so that they are expected to achieve the objectives of this study. The purpose of this study is to produce a HOTS-based instrument to produce a HOTS instrument based on Tri Hita Karana, which is a content valid, item valid, reliable instrument, good instrument in terms of distinguishing power and difficulty level. Thus, the development of a HOTS instrument based on Tri Hita Karana was carried out on theme 7 (The Beauty of Diversity in My Country) fourth grade of elementary school to increase teachers' understanding of the HOTS instrument and improve students' understanding of solving problems.

\section{METHOD}

This type of research is development research. Borg and Gall development model (Amirzan, 2017) consists of 10 steps, namely: 1) conducting preliminary research (pre-survey), 2) planning, 3) developing the type/form of the initial product, 4) conducting field trials, 5) revising the main product, 6) field trials main (wider), 7) revision of an operational product, 8) operational field test (feasibility test), 9) revision of final product (final revision), and 10) product dissemination and implementation. However, in this study, the steps taken in the development of Borg and Gall were simplified into six steps development, namely: (1) research and data collection, (2) planning, (3) initial product development, (4) field trials (limited), (5) 
revision of field test results, and (6) dissemination and implementation. The subjects in this study were 5 instrument experts and fifth grade elementary school students in 3 elementary schools, namely SD $\mathrm{N}$ Kedisan, SD N 1 Terunyan and SD N 1 Buahan. The method used to collect data in this study is the test method. An instrument can be said to be good if it meets the requirements of content validity. Instruments are arranged so that they can be valid. Then the content validity test can be carried out by several experts (judges) who have mastered the variables being studied.

The analysis used in this research includes content validity, item validity test, reliability test, difficulty level test, discriminatory power test, and distractor effectiveness. The instrument's validity is used to determine whether it is valid or not. The instrument's validity is divided into 2, namely the content validity test, which is a technique to examine whether the items of the instrument already represent the learning material as a whole or otherwise it is not representative. In this study, the analysis of the content validity test used calculations according to the CVR formula. The second item validity test determines the number of valid and failed test items. The correlation method used to calculate the validity of the objective test items is the point-by-serial correlation method ( $\mathrm{ypbi}$ ). Test reliability is used to measure the fit between the test or instrument and the person being surveyed. The reliability test was carried out after the validation test was completed. The reliability of the measuring instrument for students' HOTS abilities was sought using the KR20 formula (Kuder Richardson 20) because the items were dichotomous. Task difficulty is a measure of the quality of a task, whether it is difficult, moderate, or easy. Characteristics of items, namely items that can distinguish students' abilities. Distinguishability tests items to determine the suitability of the questions and distinguish between gifted students (high performers) and low performing students (low achievers). The effectiveness of one of the answer choices is a true distractor and a false answer choice, so that other distractor.

\section{RESULT AND DISCUSSION}

\section{Result}

At the research stage and data collection was carried out at SD N Kedisan. The initial research aims to identify and identify weaknesses related to the assessment techniques and instruments used in the school, especially the fifth grade of elementary school. Data were collected by using the observation method. The observation data found that the teacher was still making assessments with question instruments that did not encourage students to use their critical thinking skills. In addition, the questions used by teachers to measure students' abilities are not following the reality of students or close to students. The teacher also only downloads questions on the internet and does not make them himself. So it was concluded that SD N Kedisan needed an instrument that spurred students to think critically and an instrument appropriate to their circumstances. The instrument synthesizes the theory based on the variable concept to be measured and constructed at the planning stage. Make a grid in a specification table that contains dimensions, indicators, item numbers and the number of items for each dimension and indicator.

At the initial product development stage, the variable dimensions and indicators are developed according to the variable construct formulation, create a grid in the form of a specification table that contains dimensions, indicators, item numbers and number of items for each dimension and indicator, determines the quantities that move in a range from one pole to another opposite pole, writing instrument items both in the form of questions and statements, the items written are theoretically and empirically valid. The first validation, namely theoretical validation, is carried out through expert examinations or panelists who assess how far the accuracy of the dimensions as a description of the construct, indicators as a description of dimensions and items as a description of indicators and then revises the instrument based on expert advice. The results of the content validity of the HOTS instrument based on Tri Hita Karana using the CVR (Content Validity Ratio) formula which were assessed by five judges' tests totaling 20 items based on the validation provisions of each instrument item in the CVR formula according to Anzwar, all items of the HOTS instrument were declared valid. The test used is a multiple choice test. The HOTS instrument grid can be seen in Table 1 .

Table 1. HOTS instrument grid

\begin{tabular}{|c|c|c|c|c|c|}
\hline $\begin{array}{c}\text { Core } \\
\text { Competencies }\end{array}$ & $\begin{array}{c}\text { Basic } \\
\text { competencies }\end{array}$ & Indicator & $\begin{array}{c}\text { Cognitive } \\
\text { domain/ } \\
\text { Knowledge }\end{array}$ & $\begin{array}{c}\text { Test } \\
\text { Number }\end{array}$ & $\begin{array}{c}\begin{array}{c}\text { Number } \\
\text { of } \\
\text { Questions }\end{array} \\
\end{array}$ \\
\hline 3. & Scie & & & & \\
\hline $\begin{array}{l}\text { Understanding } \\
\text { factual knowledge }\end{array}$ & $\begin{array}{l}3.3 \text { Identify types } \\
\text { of forces, including }\end{array}$ & $\begin{array}{l}\text { 3.3.1 Analyzing } \\
\text { the use of }\end{array}$ & $\begin{array}{c}\mathrm{C} 4 \\
\text { (Conceptual) }\end{array}$ & $\begin{array}{l}1 \\
2\end{array}$ & 2 \\
\hline
\end{tabular}

I Wayan Sariarta / Higher Order Thinking Skills (Hots) Instrument Based on Tri Hita Karana on Theme "The Beauty of Diversity in My Country" 


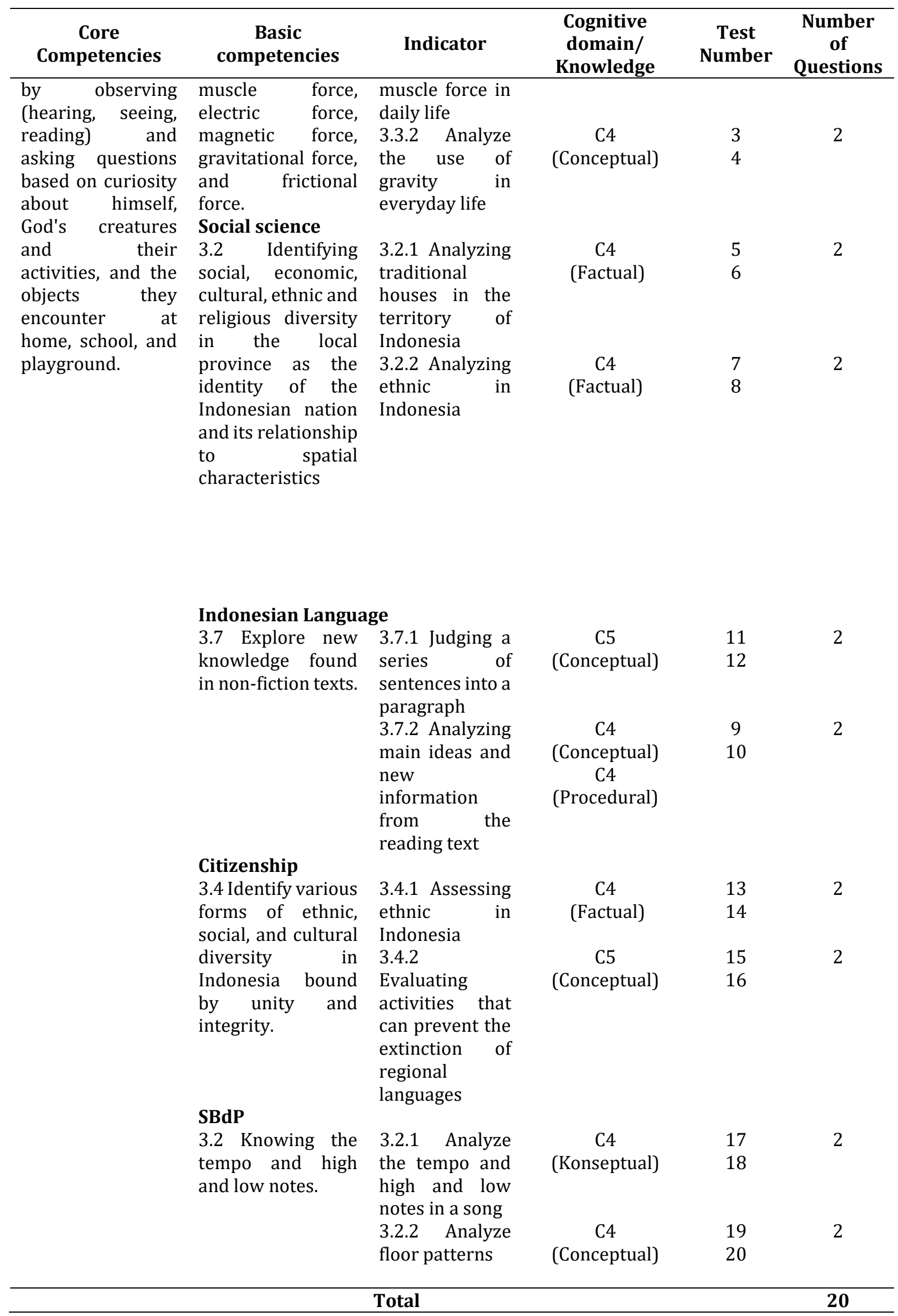


After the instrument was theoretically valid, the instrument was conducted an initial field trial by spreading the instrument to 3 elementary schools, namely SD N Kedisan, SD N 1 Terunyan, and SD 1 Buahan. After the students answered the questions, the students' answers and the data obtained were analyzed for item validity test, reliability test, item difficulty level test, and difference power test. The average result of instrument validity at SD N Kedisan is $0.660>0.432$ ( $\mathrm{ypbi}>\mathrm{r}$ table). It means that the instrument validity is declared valid, the average instrument validity at SD N 1 Terunyan is $0.624>0.514$ (ypbi>r table) meaning that the instrument validity is declared valid, the average instrument validity at SD N 1 Buahan is $0.629>0.468$ (pbi $>$ r table) meaning that the validity of the instrument is declared valid. Overall, the average results of the HOTS instrument validity test based on Tri Hita Karana on theme 7 (The Beauty of Diversity in My Country) in each school were declared valid, which means that each item of the questions has parallels or correlations with the total score. After being tested for item validity, the reliability test of the HOTS ability instrument on students uses the KR-20 formula (Kuder Richadson 20). The average instrument reliability test results at SD N Kedisan, SD N 1 Terunyan, and SD N 1 Buahan were 0.931 which was in very high criteria, it means that the HOTS instrument based on Tri Hita Karana on theme 7 (The Beauty of Diversity in My Country) is reliable. Furthermore, the data were analyzed for the difficulty level. The HOTS instrument based on Tri Hita Karana on theme 7 (The Beauty of Diversity in My Country) was difficult, medium or easy. The average difficulty level score of 0.545 is in the moderate difficulty level category. It means that the HOTS instrument based on Tri Hita Karana on theme 7 (The Beauty of Diversity in My Country) has questions with a moderate difficulty level. Next, an analysis of the differentiating power of the HOTS instrument based on Tri Hita Karana theme 7 (The Beauty of Diversity in My Country) was conducted. The analysis was carried out to see the ability of the items to distinguish capable students from students who were unable to master teaching materials and data. The average difference test results in SD N Kedisan, SD N 1 Terunyan, and SD N 1 Buahan is 0.5, which is on the criteria for a different power of Good. It means the items are good and can distinguish capable students from students who cannot master the teaching material. After the initial field test, the instrument was carried out in the product revision phase of the initial field test results. Because all items were declared valid, the instrument was not revised. Furthermore, the dissemination and implementation stages were not carried out due to limited situations and conditions, so the development stage was carried out until the initial field test stage and product revision of the initial field test results.

\section{Discussion}

Based on the results of the data analysis, the HOTS instrument based on Tri Hita Karana on theme 7 (The Beauty of Diversity in My Country) is appropriate to measure students' HOTS ability in solving problems. The HOTS instrument compiled is an instrument that measures three aspects of ability such as analyzing, evaluating, and creating. Based on this explanation, the development of the HOTS instrument needs to be done to produce a weighted question instrument that hones students' higher-order thinking skills. The questions developed are following the indicators. The questions developed can measure the selected cognitive abilities. The number of questions that already represent the Basic Competencies and the language used do not cause different interpretations with the intent of the questions. The instrument developed will be used properly by paying attention to these aspects. The developed instrument has a communicative and easy-to-understand language. Sentences in instrument statements will affect students' answers. If students do not understand the question, it will confuse them with answers. Students may answer statements that are not understood arbitrarily (Yugakisha \& Jayanta, 2021). Apart from that, in developing the instrument, clear steps are needed.

The instrument development stage has several stages, namely the curriculum analysis stage (Basic Competency analysis, indicators and materials), the stage of making the instrument grid adjusted to the assessment instrument carried out, the stage of making the instrument adjusted to the developed indicators (Safitri \& Harjono, 2021). Also, during the development of the HOTS evaluation toolkit, the HOTS question categories and the questions corresponding to the HOTS question category development process were adapted. The question's characteristic is that the question must be met to be included in the HOTS question category. For example, the syllabus used, the ability to be measured, the format of the questions developed (Widhiyani et al., 2019; Wulandari et al., 2020). So, a good instrument can show the success of the learning process. So it is deemed necessary to develop an instrument following the characteristics of students. The questions' characteristics must be met so that the questions are classified as HOTS questions, for example, the curriculum used, the competencies measured, the form of questions developed and others (Widhiyani et al., 2019; Wulandari et al., 2020).

This research is supported by research that states that the developed HOTS ability assessment instrument is feasible to develop (Fitriani et al., 2018). Research shows that the test instrument was developed with a 4D model, the feasibility of the test instrument getting an overall average of 3.8 with very good criteria and getting a PA of $93.5 \%$ with reliable criteria, the response with 6 students getting a

I Wayan Sariarta / Higher Order Thinking Skills (Hots) Instrument Based on Tri Hita Karana on Theme "The Beauty of Diversity in My Country" 
percentage of $76.4 \%$ with positive criteria, while the response with 11 students got a percentage of $93.9 \%$ with very positive criteria, the implementation of the first learning got $87.7 \% \mathrm{PA}$, the second meeting got 89.7\% PA and the third meeting got $91.7 \%$ PA so that we get reliable criteria (Hanik \& Ngazizah, 2020). This research is also supported by research showing that the HOTS-based assessment instrument developed in the form of 15 multiple choice questions and 5 description questions on the material, construction, and language aspects was declared theoretically valid based on expert judgment and empirically valid and reliable instrument based on the results of trial analysis. in the field (Rusudianto et al., 2020). Research states that HOTS is the highest level in the hierarchy of cognitive processes. HOTS enables students to tackle the challenges of being too informational in this information age, but time for processing is limited. HOTS occurs when a person acquires new information, stores it in memory, organize it, relates it to existing knowledge, and generates this information to achieve a goal or solve a complex problem (Yee et al., 2015). In addition, the research found that explicit HOTS learning in learning and assessment can positively affect students' linguistic learning in terms of the learning process, performance in assessment, creativity, and learning motivation (Nguyễn, 2017). So it is believed that the HOTS instrument based on Tri Hita Karana on theme 7 (The Beauty of Diversity in My Country) is suitable for use in elementary schools in measuring students' HOTS abilities in solving problems. The advantage of this research is developing a HOTS instrument based on Tri Hita Karana by instilling the concept of everyday life so that the questions produced are close to students and contribute to develop the HOTS instrument. The difference between this study and previous studies is that this study developed a HOTS instrument based on the Tri Hita Karana, while previous studies only developed a HOTS instrument.

The implication of this research is the production of HOTS instruments based on Tri Hita Karana on theme 7 (The Beauty of Diversity in My Country) with items that have very high item validity and very good reliability. Teachers can use this instrument to measure students' HOTS ability in solving problems. The HOTS instrument can make students think critically creatively in solving a problem they face. The prepared HOTS questions are related to everyday phenomena in the HOTS instrument based on Tri Hita Karana. The concept of Tri Hita Karana emphasizes the relationship between humans and God, the relationship between humans and humans and the relationship between humans and plants. The problems arranged in the questions are related to everyday life events so that students can easily understand the flow of problems given by the teacher. The suggestions that can be submitted to the various parties concerned. The instrument designed is expected to help students in training solve problems faced both inside and outside school to face anything independently. The development of this instrument is expected as reference material, teachers in designing HOTS instruments to measure students' HOTS abilities in solving problems. Other researchers can continue to develop HOTS instruments with different themes or develop different HOTS instruments with more creative and innovative questions.

\section{CONCLUSION}

Research on the development of the Tri Hita Karana-based HOTS Instrument as a whole, the average results of the Tri Hita Karana-based HOTS instrument validity test on theme 7 (The Beauty of Diversity in My Country) in each school were declared content valid, item valid, the instrument had a very good level of reliability. The instrument was very well tested from the aspect of distinguishing power and the instrument was very well tested from the aspect of the difficulty level. So that the HOTS instrument based on Tri Hita Karana on theme 7 (The Beauty of Diversity in My Country) is appropriate to be used to measure students' HOTS abilities in solving problems and assist teachers in understanding the HOTS instrument.

\section{REFERENCES}

Amirzan. (2017). Pengembangan Model Pembelajaran Gerak Dasar Lokomotor Pada Siswa SD Kelas V. Physical Education, Health and Recreation, 2(1). https://doi.org/10.24114/pjkr.v2i1.7843.

Anggraini, N. P., Budiyono, \& Pratiwi, H. (2019). Analysus Of Higher Order Thingking Skills Student at Junior High school in Surakarta. Journal of Physics, 12(1), 1-9. https://iopscience.iop.org/article/10.1088/1742-6596/1211/1/012077.

Arifin, Z., \& Retnawati, H. (2017). Pengembangan Instrumen Pengukuran Higher Order Thingking Skills Matematika Siswa Kelas Kelas X. Pythagoras: Jurnal Pendidikan Matematika, 12(1), 98-108. https://doi.org/10.21831/pg.v12i1.14058.

Arsana, I. N., \& Muniksu, I. M. S. (2020). Peranan Ajaran Tri Hita Karana Dalam Menanamkan Karakter Siswa Sekolah Dasar. Sang Acharya: Jurnal Profesi Guru, 1(2), 67-75. https://ejournal.ihdn.ac.id/index.php/ppg/article/view/1846. 
Bahasoan, A. N., Ayuandini, W., Mukhram, M., \& Rahmat, A. (2020). Effectiveness of Online Learning In Pandemic Covid-19. International Journal Of Science, Technology \& Management, 1(2), 100-106. https://doi.org/doi.org/10.46729/ijstm.v1i2.30.

Dahlan, D. (2010). Teacher's Competence and Difficultes in Constructing HOTS Instruments In Economics Subject. Jurnal Cakrawala Pendidikan, 39(1). https://doi.org/10.21831/cp.v39i1.28869.

Dinni, H. N. (2018). HOTS ( High Order Thinking Skills ) dan Kaitannya dengan Kemampuan Literasi $\begin{array}{lrrr}\text { Matematikar } & \text { Prisma, 170-176. }\end{array}$ https://journal.unnes.ac.id/sju/index.php/prisma/article/view/19597.

Fitriani, D., Suryana, Y., \& Hamdu, G. (2018). Pengembangan Instrumen Tes Higher-Order Thinking Skill pada Pembelajaran Tematik Berbasis Outdoor Learning di Sekolah Dasar Kelas IV. Indonesian Journal of Primary Education, 2(1), 87-96. http://ejournal.upi.edu/index.php/IJPE/index.

Hanik, A., \& Ngazizah, N. (2020). Pengembangan Instrumen Tes Berbasis Higher Order Thinking Skills ( Hots ) Kelas V Madrasah Ibtidaiyah Development of Test Instruments Based on Higher Order Thinking Skills ( Hots ) Class V Madrasah Ibtidaiyah. Jurnal Pendidikan Dasar, 10, 74-84. https://doi.org/10.37729/jpd.v2i1.967.

Hosnan, M. (2014). Pendekatan Saintifik dan Konstektual dalam Pembelajaran Abad 21: Kunci Sukses Implementasi Kurikulum 2013. Ghalia Indonesia.

Jaya, K. A. (2019). Membangun Mutu Pendidikan Karakter Siswa Melalui Implementasi Ajaran Tri Hita Karana. Jurnal Penjaminan Mutu, 5(1), 57. https://doi.org/10.25078/jpm.v5i1.759.

Khotimah, R. P., \& Sari, M. C. (2020). Pengembangan Lembar Kerja Peserta Didik Berbasis Higher Order Thinking Skills (HOTS) Menggunakan Konteks Lingkungan. Jurnal Aksioma, 9(3). https://doi.org/10.24127/ajpm.v9i3.2909.

Kwangmuang, P. (2021). The development of learning innovation to enhance higher order thinking skills for students in Thailand junior high schools. Journal Heliyon, $7(6)$. https: //doi.org/10.1016/j.heliyon.2021.e07309.

Lestari, A. (2016). Pengembangan Soal Tes Berbasis Hots Pada Model Pembelajaran Latihan Penelitian Di Sekolah Dasar. Jurnal Ilmiah Pendidikan Guru Sekolah Dasar, 3(1). https://ejournal.upi.edu/index.php/pedadidaktika/article/view/4801/3364.

Msosa, A., Bruce, J., \& Crouch, R. (2021). Effect of a formative assessment intervention on nursing skills laboratory learning in a resource-constrained country. Nurse Education Today, 97(October 2019), 104677. https://doi.org/10.1016/j.nedt.2020.104677.

Mudana, I. G. (2017). Practice of Bali Tourism Development, Threefolding, and Tri Hita Karana Local Knowlegde in Order Indonesia. The 2nd International Joint Conference on Science and Technology, 953(012108), 1-13. https://doi.org/10.1088/1742-6596/953/1/012108.

Nguyễn, T. M. T. (2017). Influence Of Explicit Higher-Order Thinking Skills Instruction On Students' Learning Of Linguistics. Journal Thinking Skil and Creativity, 26. https://doi.org/10.1016/j.tsc.2017.10.004.

Nisa, S., \& Pahlevi, T. (2021). Pengembangan Instrument Penilaian HOTS Berbantuan Quizizz pada Mata Pelajaran Kearsipan SMK. EDUKATIF: Jurnal Ilmu Pendidikan, 3(5), 2146-2159. https://doi.org/10.31004/edukatif.v3i5.756.

Noprinda, C. T., \& Soleh, S. M. (2019). Development Of Student Worksheet Based On Higher Order Thinking Skill (Hots ). Indonesian Journal of Science and Mathematics Education, 02(2), 168-176. https://doi.org/10.24042/IJSME.V2I2.4342.

Nursamsu dan Baihaqi. (2016). Implementasi kurikulum 2013 bagi guru SMA negeri Aceh Tamiang. Jurnal Pendidikan Biologi. 5(3), 193-199.

Padnyawathi \& Agustika. (2019). Pengaruh Model Pakem Berbasis Tri Hita Karana Terhadap Keterampilan Menulis. International Journal of Emelentary Education, 3(1).

Palguna, D. I. B. M. (2011). Leksikon Hindu. CV Zalfindo Perdana.

Pratiwi, H. P. (2017). Developing HOTS Modules For Sociology Learning Assessment Course. Jurnal Cakrawala Pendidikan, 34(2). https://doi.org/10.21831/cp.v36i2.13123.

Pratiwi, P. H. (2017). Pengembangan Modul Mata Kuliah Penilaian Pembelajaran Sosiologi Berorientasi HOTS. Cakrawala Pendidikan, 36(2), 201-209. https://doi.org/10.21831/cp.v36i2.13123.

Primayana, Kadek Hengki. (2018). Based On The Values Of Local Wisdom Tri Hita Karana And Spiritual Intelligence On Teacher Organiztional Commitments. Jurnal STAHN Mpu Kuturan Singaraja, 3(1).

Putra, K. R. A., Artawan, G., \& Putrayasa, I. B. (2014). Pengembangan Bahan Ajar Bahasa Indonesia Pada Topik Teks Laporan Observasi Berbasis Tri Hita Karana Untuk Siswa Kelas VIIi Smp Negeri 1 Gianyar Bali. Jurnal Ilmiah Pendidikan Dan Pembelajaran Ganesha, 1. https://media.neliti.com/media/publications/206974-pengembangan-bahan-ajar-bahasaindonesia.pdf.

Rahayu, S., Ladamay, I., Wiyono, B. B., Susanti, R. H., \& Purwito, N. R. (2021). Electronics Student Worksheet 
Based on Higher Order Thinking Skills for Grade IV Elementary School. International Journal of Elementary Education, 5(2), 453. https://doi.org/10.23887/ijee.v5i3.36518.

Rusudianto, A. R., Susanta, A. S., \& Muktadir, A. M. (2020). Pengembangan Instrumen Penilaian Berbasis Higher Order Thinking (Hot) Pelajaran Matematika Kelas IV Sekolah Dasar. Jurnal Pembelajaran Dan Pengajaran Pendidikan Dasar, 3(1), 1-19. https://doi.org/10.33369/dikdas.v3i1.12110.

Safi'i, I dan Amar, F. (2019). Pelatihan Penyusunan Instrumen Evaluasi Berstandar HOTS Bagi Guru-Guru SD di Wilayah Banyudono. Jurnal Abdimas Dewantara, 2(2).

Safitri, K., \& Harjono, N. (2021). Pengembangan Instrumen Penilaian Sikap Sosial Aspek Tanggung Jawab Pembelajaran Tematik Terpadu Siswa Kelas 4 SD. Jurnal Pedagogi Dan Pembelajaran, 4(1), 111. https://doi.org/10.23887/jp2.v4i1.33352.

Saputra, H. (2016). Pengembangan Mutu Pendidikan Menuju Era Global: Penguatan mutu Pembelajaran dengan Penerapan HOTS (Higher Order Thingking Skills). Smiles Publishing.

Schildkamp, K., van der Kleij, F. M., Heitink, M. C., Kippers, W. B., \& Veldkamp, B. P. (2020). Formative assessment: A systematic review of critical teacher prerequisites for classroom practice. International Journal of Educational Research, 103(April), 101602. https://doi.org/10.1016/j.ijer.2020.101602.

Slamet, P. (2016). Indonesian Education Politics In The Twenty First Century. Jurnal Cakrawala Pendidikan, $33(3)$.

Suarmini. (2019). Metode Gamfikasi Berbasis Tri Hita Karana Sebagai Alternatif Pembelajaran Abad 21. Jurnal Pendidikan, Agama Dan Budaya, 2(2).

Sudarsana, I. K. (2018). Pengaruh model pembelajaran kooperatif terhadap peningkatan mutu hasil belajar siswa. Jurnal Penjaminan Mutu, Lembaga Penjaminan Mutu, Institut Hindu Dharma Negeri Denpasar, $4(1), 20-31$.

Sufairoh. (2016). Pendekatan saintifik \& model pembelajaran K-13. Jurnal Pendidikan Profesional. 5(3), 116125.

Susilana, R., \& Rusman. (2015). Implementasi kurikulum 2013 di sekolah dasar. Edutech, 1(1), 52-67.

Wahyudin, Y., Rusman, D., \& Rahmawati. (2017). Penguatan life skills dalam implementasi kurikulum 2013 pada SMA (sekolah menengah atas) di Jawa Barat. Mimbar Pendidikan: Jurnal Indonesia Untuk Kajian Pendidikan, 2(1), 65-80.

Widhiyani, I. A. N. T., Sukajaya, I. N., \& Suweken, G. (2019). Pengembangan Soal Higher Order Thinking Skills Untuk Pengkategorian Kemampuan Pemecahan Masalah Geometri Siswa Smp. Jurnal Pendidikan Dan Pembelajaran Matematika Indonesia, 8(2), 68-77. https://doi.org/10.23887/jppm.v8i2.2854.

Winaryati, E. (2018). Penilaian Kompetensi Siswa Abad 21. Seminar Nasional Edusaintek.

Wulandari, S., Hajidin, H., \& Duskri, M. (2020). Pengembangan Soal Higher Order Thinking Skills (HOTS) pada Materi Aljabar di Sekolah Menengah Pertama. Jurnal Didaktik Matematika, 7(2), 200-220. https://doi.org/10.24815/jdm.v7i2.17774.

Yee, M. H., Yunos, J. M., Othman, W., Hassan, R., Tee, T. K., \& Mohamad, M. M. (2015). Disparity of Learning Styles and Higher Order Thinking Skills among Technical Students. Procedia - Social and Behavioral Sciences, 204(November 2014), 143-152. https://doi.org/10.1016/j.sbspro.2015.08.127.

Yugakisha, M. S., \& Jayanta, I. N. L. (2021). Instrumen Penilaian Motivasi Belajar IPA. Jurnal Pedagogi Dan Pembelajaran, 4(3), 402. https://doi.org/10.23887/jp2.v4i2.35918.

Yunita, N. K. D., \& Tristiantari, N. K. D. (2018). Pengaruh Model Pembelajaran Kooperatif Tipe TGT Berbasis Kearifan Lokal Tri Hita Karana Terhadap Hasil Belajar. Jurnal Pendidikan Multikutural Indonesia, $1(2)$.

Zhang, X. (2020). Assessment for learning in constrained contexts: How does the teacher's self-directed development play out? Studies in Educational Evaluation, 66(November 2019), 100909. https://doi.org/10.1016/j.stueduc.2020.100909. 